5) навчально-виховному процесу притаманні оптимістичний настрій, загальна атмосфера радості, взаємодопомоги, толерантності, людяності.

Апробація цієї моделі у 2018 - 2019 навчальному році при викладанні дисциплін психолого-педагогічного циклу дає підстави стверджувати, що ідеї людиноцентризму і дитиноцентризму педагогіки Василя Сухомлинського сприятимуть підготовці сучасних та успішних педагогів.

\section{СПИСОК ВИКОРИСТАНОЇ ЛІТЕРАТУРИ}

1. Антонець М. Я. Проблеми діяльності вчителя у педагогічній спадщині Василя Сухомлинського : монографія / М. Антонець. - Вид. 3-є, доповн. - К. : Четверта хвиля, 2010. - 212 с.

2. Богуславський М. В. Школа самореалізації особистості у трактуванні В. О. Сухомлинського / М. В. Богуславський // Директор школи. - 1998. Число 26 (38). - С. 3.

3. Розенберг А. Я. Педагогіка Василя Сухомлинського як цілісна виховна система / А. Я. Розенберг // Педагогіка і психологія. - 2013. - № 2. - С. 11-19.
4. Савченко О. Я. Формування і розвиток у школярів уміння вчитися: досвід В. О. Сухомлинського / О. Я. Савченко // Наукові записки / ред. кол. : В. В. Радул, С. П. Величко та ін. - Вип. 123. - Т. 1. - Кіровоград : Імекс-ЛТД, 2013. - 356 с. - (Серія «Педагогічні науки»).

5. Сухомлинська О. В. Школа Сухомлинського у Павлиші - погляд крізь призму часу : науково-популярне видання / О. В. Сухомлинська. - К. : Педагогічна думка, 2013. - 124 с.

6. Сухомлинський В. О. Вибр. твори : у 5 т. / В. О. Сухомлинський. - К. : Рад. шк., 1976.

7. Сухомлинський В. О. Вибр. твори : у 5 т. / В. О. Сухомлинський. - К. : Рад. шк., 1977.

8. Сухомлинський В. О. Директор школи - керівник навчально-виховної роботи : дис... канд. пед. наук. / В. О. Сухомлинський ; машинопис з авторською правкою // УДАВО України, ф. 5097, оп. 1. арк. 27-45.

9. Сухомлинський В. О. Моя педагогічна система / В. О. Сухомлинський // Радянська школа. - 1988. № 6-9.

Дата надходження до редакиії: 19.08.2019 p.
УДК 37.091.4:37.3/5.091.6

DOI: $10.37026 / 2520-6427-2019-99-3-45-48$
Інна ПЕТРЕНКО,

здобувачка кафедри теорї і методики виховання

Рівненського держсавного гуманітарного університету

\title{
ВАСИЛЬ СУХОМЛИНСЬКИЙ: ПРО КЛАСНУ КІМНАТУ ЯК ВАЖЛИВУ СКЛАДОВУ ОСВІТНЬОГО СЕРЕДОВИЩА
}

У статті схарактеризовано погляди В. Сухомлинського шодо облаштування класної кімнати як важливої складової освітнього середовищза. 3'ясовано, що педагог у прачях «Павлиська середні школа», "Серие віддаю дітям» значну увагу приділив опису матеріальної бази Павлиської школи, облаштуванню класних кімнат, зокрема детально описав класну кімнату початкової школи, кабінети основної школи (математики, мови і літератури, іноземної мови та ін.), характеристичі «зелених класів» як складової освітнього середовища.

Ключові слова: Василь Сухомлинський, Павлиська середня школа, освітнє середовище, класна кімната, «зелений клас».

В статье охарактеризованы взгляды В. Сухомлинского по обустройству классной комнатьл как важной составляющей образовательной среды. Выяснено, что педагог в работах «Павльишская средняя икола", "Сердие отдаю детям» особое внимание уделил описанию материальной базы Павльшиской школь, обустройству классных комнат, в частности подробно описал классную комнату начальной школь, кабинеть основной школь (математики, языка и литературы, иностранного языка и др.), характеристике «зеленых классов» как составляющей образовательной среды.

Ключевые слова: Василий Сухомлинский, Павльшиская средняя школа, образовательная среда, классная комната, «зеленый класс».

In article the author describes the views of V. Sukhomlynskyi on the arrangement of the classroom as an important component of the educational environment. We found out that in the native pedagogy Vasyl Sukhomlynskyi one of the first drew attention to a set of factors of school life, which carry out both direct and indirect influence on the formation of the student's personality and called them a «background». The author proved that for V. Sukhomlynskyi school buildings, its material base is also a «necessary condition for a fully-fledged pedagogical process», and «a means of influencing the spiritual world of pupils». 
In the writings «Pavlyshka High School», "Heart I give to children", the teacher paid a lot of attention to the description of the material base of the Pavlyshka school, the atmosphere of classrooms.

The attention of the pedagogical staff of Pavlyshka school was focused on well thought out and well-balanced arrangement of school premises and classrooms. V. Sukhomlynskyi described in detail the classroom for elementary school pupils, which had their own household (flowerpots, cabinets (with notebooks, pencils, visual aids, materials for manual labor), table, ruler or meter (for work on a board), a compass, a pointer, a box with a color chalk), an economic corner (needles, threads, buttons, cloths, cloths of fabric). The teacher describes in detail the arrangement of the offices of the main school: mathematics, language and literature, foreign language, etc.

Significant place in the writings of the teacher is the characteristic of the "green classes》 (arbours, cherished wild grapes and hops and lawns, surrounded on three sides by a frost-resistant grape variety) as a component of the educational environment of the Pavlyshka School.

The analysis of $V$. Sukhomlynskyi's works allows us to assert that all premises, corridors, and classrooms were designed at the school in accordance with the age, the interests of children, and they had to "call for something, learn something» for children.

Key words: V. Sukhomlynskyi, Pavlyshka secondary school, educational environment, classroom, "green class».

Постановка проблеми. Формула нової школи відповідно до Концепції «Нова українська школа» передбачає наявність дев'яти ключових компонентів, серед яких важливою складовою визначено і «сучасне освітнє середовище, яке забезпечить необхідні умови, засоби і технології для навчання учнів, освітян, батьків не лише в приміщенні навчального закладу» [3, с. 11]. Саме формування особливого освітнього середовища дасть змогу здійснити гуманізацію освіти, гарантувати дотримання прав людини, задовольнити індивідуальні потреби суб'єктів освітнього процесу. Освітнє середовище покликане відображати філософію Концепції Нової української школи та освітню програму, згідно 3 якою «освітнє середовище створюється для заохочення самовизначення дітей у класі та розвитку їхніх спроможностей, оскільки відомо, що люди, які контролюють те, що відбувається з ними, краще адаптовані до життя» [3, с. 53]. Така орієнтація сучасної освіти спонукає освітян актуалізувати наявні ідеї й обгрунтовувати нові підходи, що забезпечить ефективну реалізацію формули Нової української школи. У зв'язку з цим актуальності набувають дослідження педагогічних ідей видатних педагогів минулого щодо створення сприятливого освітнього середовища.

Одним із перших вітчизняних педагогів, хто почав будувати педагогічну систему, створюючи сприятливе освітньо-виховне середовище, був Василь Олександрович Сухомлинський, адже, на думку педагога, виховують «не лише людські стосунки, не лише приклад і слово старших, не тільки традиції, що дбайливо зберігаються в колективі, а й речі - матеріальні й духовні цінності. Виховання середовищем, обстановкою, створеною самими учнями, речами, що збагачують духовне життя колективу, - це, на наш погляд, одна 3 найтонших сфер педагогічного процесу» [8, с. 89].

Аналіз наукових досліджень і публікацій. Вивченням освітнього середовища закладу середньої освіти займалися В. Панов, Н. Поліванова, В. Слободчиков [4]. Предметно-просторове середовище закладу освіти досліджували Г. Балл, І. Бех, С. Бондаревська, Дж. Гібсон, В. Рибалка, В. Семиченко, В. Серіков та ін. Сукупність системи впливів, можливостей, умов розвитку особистості в освітньому середовищі аналізували В. Вербицький, С. Дерябо, О. Коберник, Н. Поліванова, В. Слободчиков, В. Ясвін та ін. [11]. Погляди В. Сухомлинського стосовно освітнього середовища Павлиської середньої школи обгрунтовували М. Библюк, О. Петренко, О. Сухомлинська, Т. Хрєнова та ін. $[1 ; 5 ; 6]$.

Мета статті - проаналізувати погляди Василя Сухомлинського на класну кімнату як важливу складову освітнього середовища.

Виклад основного матеріалу. Видатний український педагог, директор Павлиської середньої школи Василь Сухомлинський вважав школу тим місцем, де дитина повинна відчувати щастя повноти свого духовного життя, радість праці й творчості. Він підходив до шкільного інституту діалектично - від незвичайної «школи під голубим небом», школи природи і чуттєвого, емоційно-конкретного сприйняття світу, до школи як вогнища духовності, культури, місця раннього прилучення до моральних цінностей, місця вирішення протиріч, конфліктів, ідейних зіткнень [6, с. 12].

У вітчизняній педагогіці Василь Сухомлинський одним із перших звернув увагу на сукупність факторів шкільного життя, які здійснюють як прямий, так i опосередкований вплив на становлення особистості школяра і назвав їх «фоном» [9]. Створене В. Сухомлинським освітне середовище було покликане формувати в дитини особистісне емоційне ставлення до себе, до природи й навколишнього світу, дарувати їй радість пізнання, «відкриття світу», єднання із навколишнім середовищем [10, с. 45]. Він зокрема зазначав: «Матеріальну базу школи ми розглядаємо в нерозривній єдності з обстановкою, до якої входить природа, праця і суспільна діяльність навколишніх людей» [8, с. 89].

Школа як заклад освіти складається із багатьох класних кімнат. Учні в закладі освіти працюють у певних матеріальних умовах, які відчутно впливають на процес освіти: класна кімната, іiі оформлення, розташування меблів, особисті речі учнів, температурні та гігієнічні умови, освітлення, чистота тощо. Дитина сприймає все це, по-перше, крізь призму навчального призначення і ставиться до цього так, як до самого навчального предмета. По-друге, будь-який предмет, і навіть умови (освітлення, температура), мають певну матеріальну цінність, а отже, ставлення повинно бути таким, як до продукту чиєїсь праці. По-третє, будь-який матеріальний предмет $\epsilon$ також носієм певних естетичних якостей. Він може бути не лише придатним і зручним, а й гарним або негарним, тобто, стверджувати або руйнувати естетичні смаки.

Вільна енциклопедія Вікіпедія пропонує таке визначення класної кімнати: «Це - велика, спеціально обладнана кімната. Більшу частину класу займають місця для слухачів, орієнтовані в одну сторону. Як правило, наявна дошка для записів або екран для відеоінформації. $€$ можливість вивішування плакатів. У класі влаштовано багатолампове освітлення або велика кількість високих і широких вікон. У школі наявна значна кількість облаштованих класів» [2].

Саме простір класу, за дослідженнями англійських учених, найбільше впливає на успішність учнів. Для В. Сухомлинського ж будівля школи, іiі матеріальна база виступають i «необхідною умовою повноцінного педагогічного процесу», i «засобом впливу на духовний світ вихованців» [8, с. 89]. 
У Павлиші школа являла собою ціле містечко, на території якого розташовані будиночки навчального та виховного призначення. У «кожному навчальному корпусі (a їх було 7) була кімната для читання, класна бібліотека, зелений куточок, куточок відпочинку, господарський куточок» [7, с. 29]. Увага педагогічного колективу зосереджувалася насамперед на продуманому облаштуванні шкільних приміщень та класних кімнат. Як згадує донька педагога, академік Ольга Сухомлинська, «вчителі були переконані, що жодна деталь в облаштуванні шкільних приміщень не може бути випадковою, не продуманою: в кожному навчальному приміщенні обстановка відповідала вікові, інтересам і духовному життю дітей, що тут навчалися» [7, с. 28].

Василь Олександрович Сухомлинський значну увагу приділяв матеріальній базі Павлиської середньої школи, облаштуванню класних кімнат і позакласної роботи. У праці «Павлиська середня школа» окремий розділ присвячений матеріальній базі школи та обстановці, що оточує дітей $[8$, с. 89]. У Павлиші навчання різних вікових груп учнів відбувалося в різних корпусах, усі будівлі містили учительську кімнату, в якій знаходився розклад і було створено затишну атмосферу.

У приміщенні, де навчалися учні 1-2-х класів, окрім класної кімнати, було облаштовано кімнати для ігор і казок, змінні стенди «Світ у малюнках», виставку учнівських зошитів «Пиши гарно і грамотно». Велика класна кімната була розташована таким чином, що вікна, які виходили на схід та південь, пропускали в приміщення багато світла, створюючи затишну робочу атмосферу. У кожній класній кімнаті була класна «робоча дошка», на якій вивішувався список чергових учнів і список книжок для позакласного читання. У кожному навчальному будинку були живі куточки, у кожній класній кімнаті - «господарський куточок, де $\epsilon$ голки, нитки, гудзики, ганчірочки, клаптики тканини» [8, с. 102]. Кожен клас мав своє господарство: «один чи два вазони $з$ квітами, шафу (із зошитами, олівцями, наочним приладдям, матеріалами для ручної праці), арифметичну чи логарифмічну лінійку або метр (для роботи на дошці), циркуль, указку, коробку 3 кольоровою крейдою. У столі зберігають класні цінності (бібліотечку тощо)» [8, с. 102-103]. Описуючи освітне середовище початкової школи, педагог зазначав: «Під вікнами - горіхові дерева, за ними яблуні, груші, абрикоси, далі - дубовий гай. ... Листя дерев збагачують повітря киснем. На шкільній садибі завжди панує тиша. ... Перед ганком нашого будиночка - бетонований майданчик із пристроєм для миття взуття (використовується запас дощової води). Від майданчика йде кілька доріжок, обсаджених персиковими деревами, липами та каштанами» [10, с. 113].

У головному двоповерховому корпусі, де навчалися учні 5-10-х класів, поряд із класними кімнатами, що становлять особливу і найважливішу частину, спеціально оснащену для проведення навчально-виховного процесу, розташовано: кабінети математики, мови і літератури, іноземної мови, в яких були списки рекомендованої літератури для кожної вікової групи учнів, для позакласного читання французькою i німецькою мовами, рукописний журнал «Наша творчість», фонотека; радіолабораторію, в якій знаходився шкільний радіовузол і обладнання для практичних робіт із радіотехніки; музичну кімнату з фонотекою музичних творів класиків і сучасників, народними інструментами; шкільний музей із матеріалами про те, чим живе колектив; методичний кабінет, в якому розміщено педагогічну бібліотеку; куточок для батьків, де вміщено інформацію про шкільне життя дітей; фотолабораторію; куточок образотворчого мистецтва, де проводяться виставки малюнків; спортзал; ідальню; тихий куточок, обстановка якого «спонукає до роздумів, спогадів, мрій» в оточенні репродукцій картин і фонотеки; піонерську і комсомольську кімнати з бібліотекою та атрибутами; кімнату-склад інвентаря для самообслуговування [8, с. 95-96]. Крім того, в корпусі був обладнаний куточок для дівчат, де знаходилися посібники з анатомії і фізіології, про гігієну жінки, материнство [8, с. 101].

Василь Олександрович у праці «Павлиська середня школа» досить детально описав оснащення кожного кабінету [8 с. 103-108]. Аналіз цього опису дає змогу стверджувати, що всі приміщення, коридори, класні кімнати були в школі оформлені відповідно до віку, інтересів дітей. Василь Олександрович, створюючи матеріальну базу школи та обстановку, що оточувала дітей, переконував: «обстановка, що оточує дитину, повинна іiі до чогось закликати, чогось учити» [8, с.116], а також додавав: «Ми прагнемо того, щоб у школі й стіни говорили» [8, с. 122].

В. Сухомлинський намагався проводити 3 дітьми більше часу на свіжому повітрі, максимально скоротивши час перебування дітей у приміщенні та надавши перевагу заняттям на свіжому повітрі. Особливо цінною знахідкою Василя Сухомлинського була організація нестандартних «зелених класів» - альтанки, завитої диким виноградом і хмелем та галявини, оточеної з трьох сторін морозостійким сортом винограду. «Близько $40 \%$ усіх уроків протягом року ми проводили не в приміщенні, а в «зеленому класі». Із $60 \%$ класних занять значна частина в нас припадала на заняття в «зеленій лабораторії» і шкільній теплиці. «Зелена лабораторія» - це окремий будиночок, оточений деревами і кущами винограду. Тут $є$ кімната для занять, у ній велика кількість рослин і квітів», - зазначав педагог [10, с.117].

У праці «Серце віддаю дітям» Василь Олександрович детально описав облаштування «зелених класів»: «Ми разом зі старшими учнями спорудили тут 3 дроту й залізних прутів каркас майбутнього зеленого класу... Через два роки утворилася зелена кімната - рослини закрили й стелю. Кілька «віконечок» забезпечували нормальне освітлення. В спеку тут було прохолодно, восени - тепло й затишно. В зеленому класі завжди панувала тиша. «Віконечка» можна було закрити гілками хмелю та винограду і тоді наставав зелений напівморок, крізь просвіти в листі струменіли сонячні промені, утворюючи дивну гру світла й тіні. Діти називали це «закрити віконечко для казки». В зеленому класі стояли маленькі столики й стільці, тут діти писали, читали, розв'язували задачі»» [10, с. 117].

Такий підхід до організації освітнього середовища сприяв здійсненню ефективного освітнього процесу, зміцненню духовного й фізичного здоров'я дітей.

Висновки. Таким чином, презентована наукова розвідка дає змогу стверджувати, що в становленні теорії і практики збереження і зміцнення здоров'я дітей, в організації освітнього простору особливе місце займає педагогічна спадщина видатного українського педагога-практика В. Сухомлинського. Ідеї педагога щодо організації освітнього простору, облаштування класних кімнат є актуальними у контексті розбудови Нової української школи. 
Перспективи подалыших наукових розвідок вбачаємо в здійсненні порівняльного аналізу критеріїв Нової української школи та вимог В. Сухомлинського до оформлення класної кімнати початкової школи, в аналізі стендів як складової освітнього простору закладу освіти.

\section{СПИСОК ВИКОРИСТАНОЇ ЛІТЕРАТУРИ}

1. Библюк М. Прихована програма школи Василя Сухомлинського / М. Библюк // Шлях освіти. - 2004. № 1. - C. 41-45.

2. Класна кімната [Електронний ресурс]. URL: https://uk.wikipedia.org/wiki/\%d0\%9a\%d0\%bb\%d0\% b0\%d1\%81\%d0\%bd\%d0\%b0 \%d0\%ba\%d1\%96\%d0\% $\mathrm{bc} \% \mathrm{~d} 0 \% \mathrm{bd} \% \mathrm{~d} 0 \% \mathrm{~b} 0 \% \mathrm{~d} 1 \% 82 \% \mathrm{~d} 0 \% \mathrm{~b} 0$ (дата звернення: 20.06.2019).

3. Нова українська школа: порадник для вчителя / за заг. ред. Н. М. Бібік. - К. : ТОВ «Видавничий дім «Плеяди», 2017. - 206 с.

4. Панов В. И. Психодидактика образовательных систем: теория и практика. / В. И. Панов. - СПб. : Питер, 2007. $-352 \mathrm{c}$.

5. Петренко О. Б. Роль шкільного середовища Павлиської середньої школи часів В. Сухомлинського в розвитку креативності учнів / О. Б. Петренко // Спадщина В. О. Сухомлинського - джерело сучасної педагогічної науки і практики : монографія. - Луцьк : Надстир'я, 2016. - С. 63-73.

6. Сухомлинская О. В. Идеи и свершения Василия Александровича Сухомлинского / О. В. Сухомлинская // Советская педагогика. - 1988. - № 9. C. $11-17$.

7. Сухомлинська О. В. Школа Сухомлинського у Павлиші - погляд крізь призму часу : науково-популярне видання / О. В. Сухомлинська. - К. : Педагогічна думка, 2013. - 124 с.

8. Сухомлинський В. О. Павлиська середня школа / В. О. Сухомлинський // Вибрані твори : в 5 т. - К. : Рад. школи, 1977. - Т. 4. - С. 7-390.

9. Сухомлинський В. О. Розмова з молодим директором школи / В. О. Сухомлинський // Вибрані твори : в 5 т. - К. : Рад. шк., 1977. - Т. 4. - С. 393-626.

10. Сухомлинський В. О. Серце віддаю дітям / В. О. Сухомлинський // Вибрані твори : в 5 т. - К. : Рад. шк., 1976. - Т. 3. - С. 7-282.

11. Ясвин В. А. Образовательная среда: от моделирования к проектированию / В. А. Ясвин. - М. : Смысл, 2001. - 365 с.

Дата надходження до редакиї: 06.08.2019 p.

Віктор ШВИдУН, кандидат педагогічних наук, доиент, заступник декана факультету підготовки та перепідготовки педагогічних кадрів КЗВО «Дніпровська академія неперервної освіти» Дніпропетровської обласної ради, м. Дніпро

\section{УПРАВЛІННЯ ПІСЛЯДИПЛОМНОЮ ПЕДАГОГІЧНОЮ ОСВІТОЮ ЯК СКЛАДОВОЮ ОСВІТИ В УКРАЇНІ}

У статті розглядаються питання модернізаиії системи післядипломної педагогічної освіти в Україні. Визначаються основні положення методологіі післядипломної педагогічної освіти та функиї̈ педагогічного прочесу в контексті необхідності продовження реформування украӥнської школи через послідовну реалізацію комплексу взаємопов'язаних заходів.

Ключові слова: компетентність, інновачї̈, післядипломна педагогічна освіта, самоосвіта, функиії післядипломної педагогічної освіти.

В статье рассматриваются вопросы модернизаици системы последипломного педагогического образования в Украине. Определяются основные положения методологии последипломного педагогического образования и функиии педагогического проиесса в контексте необходимости продолюения реформирования украинской школь через последовательную реализаиию комплекса взаимосвязанных мероприятий.
Ключевые слова: компетентность, инновачии, последипломное педагогическое образование, самообразование, функиии последипломного педагогического образования.

The article deals with the issues of modernization of the postgraduate pedagogical education system in Ukraine. The main points of the postgraduate pedagogical education methodology are determined, since it is precisely what provides human education for most of his life. In particular, the focus is on concentrating not only on supporting traditional post-graduate education mechanisms, but on developing new ones, aimed at adapting to tasks related to systemic restructuring both in education and society as a whole. Modern postgraduate education is possible only on the basis of a combination of the actual system of postgraduate pedagogical education and self-education of teachers in the process of carrying out professional duties. That is why it is about creating a continuous system 